\title{
分散系シリコーンゲルの粘弾性特性に関する電界の効果
}

$\begin{array}{lrrr}\text { 正員 } & \text { 花岡 } & \text { 良一 } & \text { （金沢工大） } \\ \text { 正員 } & \text { 高田 } & \text { 新三 } & \text { （金沢工大） } \\ \text { 非会員 } & \text { 中澤 } & \text { 優一 } & \text { （金沢工大） } \\ \text { 正員 } & \text { 深見 } & \text { 正 } & \text { （金沢工大） } \\ \text { 非会員 } & \text { 桜井 } & \text { 宏治 } & \text { (藤倉化成） }\end{array}$

\section{Effect of Electric Field on Viscoelastic Properties in Silicone Gel of Disperse System}

\author{
Ryoichi Hanaoka*, Shinzo Takata*, Yuichi Nakazawa*, \\ Tadashi Fukami*, and Koji Sakurai** \\ (*: Kanazawa Institute of Technology, **: Fujikura Kasei Co., Ltd.)
}

\begin{abstract}
In the electrorheological (ER) fluids of the disperse system, the poor dispersion stability of particles often limits the development of practical application of the fluids. This key matter can be settled by the chemical gelation of ER fluids. In the present study, the dimethylsilicone oil-based gel containing the non-aqueous ER particles was newly created. The dynamic properties on viscoelasticity in the sample silicone gel were examined under the $D C$ applied electric field up to $2.0 \mathrm{kV} / \mathrm{mm}$ using the sinusoidal oscillating rheometer with the low frequencies of $1 \mathrm{~Hz}$ or less. The particle behavior and the shearing deformation in the sample gel were also observed using a microscope, a CCD camera and a color video monitor. When an electric field was applied to the sample gel, the gap between the electrodes was bridged by the chains of particles arranged in the direction of the electric field. Consequently, it is shown that the electroviscoelastic effect of the gel can be controlled by the electric field.
\end{abstract}

キーワード : 直流電界、分散系 $\mathrm{E} R$ 流体、分散系シリコーンゲル、電気粘弾性

\section{1.はじめに}

電界を印加すると見掛けの粘度 (または、降伏応力)が 100 倍以上も増大し、電界を除去すると元の粘度に戻るような 可逆的特性を有する流体は、E R 流体(Electrorheological Fluid: ERF) として知られ、電界によるこの特性を E R 効果 と称する(1)。代表的な流体としては分散系の E R 流体が挙げ られる。これは、絶縁性の液体(分散媒) 中に帯電していな い小さな固体粒子を適当な濃度 (普通、10４0\%程度)で分 散させた混合液からなる。固体粒子は一般に絶縁性の球形 であり、その大きさは直径 $1 \sim 50 \mu \mathrm{m}$ 程度である。粒子の 誘電率は分散媒のそれよりも大きい。また、ER効果によ る粘度変化の可逆応答性も良い(数msのオーダー)ので、こ れらの特性を利用して、電気的に直接制御可能なクラッ チ、ダンパー、バルブ等の機械的要素への応用、自動車産 業、土木建策、音響、医療分野等における振動制御、口 ボット制御、アクチュエーター制御等の幅広い制御システ ムへの応用が期待される。

分散系 $E R$ 流体に電界を印加すると、その直後に電極間
を架橋する粒子の鎖状構造が形成される。この鎖状構造が 剪断に対する抵抗力を発生して降伏応力が生じる。すなわ ち、E R効果は、流体の挙動が電界の印加によってニュー トン流体的挙動からビンガム流体的挙動へ移行することに よって発現する(2)。ER効果の発現メカニズムに関しては、 分散媒と固体粒子との誘電率不一致によって各粒子に発生

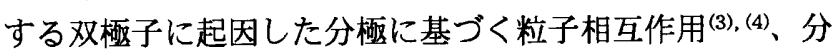
散媒中のイオンが粒子表面に選択吸着されて電気二重層を 形成し、電界の印加によって電気二重層の歪みと重なりが

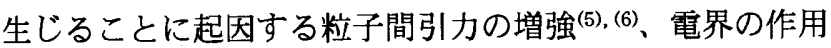
によって凝集した粒子間の水のしみ出し架橋に起因した凝

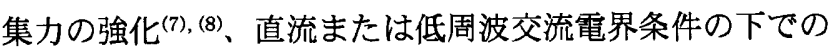
電気伝導に起因した粒子間引力の発生 ${ }^{(9)}$ (12)、などの説が報 告されているが、いずれも粒子間引力の増強に関連した理 論である。

一方、E R 流体を電気一機械変換制御要素として応用す る場合、流体が具備すべき性能としては、（1）低い電界で大 きな剪断応力が得られること（電界が $2 \sim 3 \mathrm{kV} / \mathrm{mm}$ 以下で降 
伏応力が $1 \mathrm{kPa}$ 程度以上が望ましい)(応力特性)、(2) 電界印 加時の電流密度が小さいこと $\left(10 \mu \mathrm{A} / \mathrm{cm}^{2}\right.$ 程度以下が望ま しい) (電流特性)、(3) 応力特性と電流特性が経時的に変化 しないこと(耐久性)、(4) 応力特性と電流特性が実用温度範 囲( $\left(-40 \sim+120^{\circ} \mathrm{C}\right.$ 程度) 内で安定であること(温度特性)、(5) 無電界時の粘度が小さいこと(ニュートン粘度に近いことが 望ましい) (流動性)、(6) 分散した粒子が静置状態で沈降し ないこと(分散安定性)、が举げられる。これらの性能は粒 子自身の特性に大きく左右されることから、E R 流体用粒 子の開発が活発に行われ、現在、(1)〜 (5) の性能をほぼ満 足する無水性の粒子が創製されつつある。しかし、「分散安 定性」の問題が残されている。すなわち、分散媒と粒子の比 重を完全に一致させることは極めて困難とされ、流体を長 時間静置した場合、両者の僅かな比重差によって粒子の沈 降が生じ、これが E R 特性の不安定性を導き、応用機器シ ステムの信頼性を損ねる原因となる。著者らはこの重要な 問題を解決する目的で、これまでに開発してきた無水性 $\mathrm{E}$ $\mathrm{R}$ 流体 ${ }^{(13)}$ のゲル化を提案し、 $\mathrm{E} \mathrm{R}$ 用粒子を分散したシリ コーンゲルを試作した。このような粒子分散系シリコーン ゲルの粘弾性特性に関する電界の効果を報告した例は比較 的少なく(14),(15)、その特性はまだよく理解されていないよう である。

本論文では、試作したシリコーンゲルについて、直流電 界印加時の粘弾性特性と E R 効果を調べた。得られた結果 は、 E R 材料の応用分野に新たな指標を与えるものと思わ れるのでここに報告する。

\section{2.実呤装圈と実験方法}

$<2 \cdot 1>$ 分散系シリコーンゲルの試作 使用した 固体粒子は $\mathrm{ER}$ 流体用に開発されたものであり、平均粒子 直径が約 $10 \mu \mathrm{m}$ の無水性球形粒子である。これらは、アク リル酸ブチルと1,3-ブタンジオールメタクリレートの共重 合体からなるポリマー粒子のコア表面に酸化スズ、及び酸 化チタンの微粒子を $1 \mu \mathrm{m}$ 程度の厚さで担持させた無機・有 機複合構造のものであり、藤倉化成(株)でジェット気流拡 散法により試作された。

シリコーンゲルは、上記の粒子をジメチルシリコーン油 (粘度 $\left.97 \mathrm{mPa} \cdot \mathrm{s}\left(25^{\circ} \mathrm{C}\right)\right)$ に $30 \mathrm{wt}$.\%の濃度で分散して十分に 擋汼した後、ハイドロジェンシリコーンと不飽和基含有化 合物の添加によるヒドロシリル化反応(Si-H結合)によって 生成された ${ }^{(16)}$ 。なお、粒子の濃度 (30wt.\%)は、種々の濃 度を有する $\mathrm{E} R$ 流体において顕著な $\mathrm{E} R$ 効果を発現するこ と、及び流体をゲル化した場合に粒子が電界の印加により 適当な結合状態を示すことから選定された。また、ヒドロ シリル化は、触媒の添加と加熱によってその反応速度が極 めて促進されることが知られている。この性質を利用し て、本研究では微量の白金触媒を添加し、 $90^{\circ} \mathrm{C}$ の恒温槽内 で6時間加熱することによってゲル化速度を速め、粒子沈降 の影響が無いゲルを作成した。表 1 は試作したシリコーシ
表 1 供試シリコーンゲルの代表的な物理定数

Table 1 Typical properties of silicone gel specimen.

\begin{tabular}{l|ccc}
\hline \multicolumn{1}{c|}{ 供試材料 } & $\begin{array}{c}\text { 密度 } \\
\left(\mathrm{g} / \mathrm{cm}^{3}\right)\end{array}$ & $\begin{array}{c}\text { 比誘電率 } \\
(\mathrm{f}=100 \mathrm{~Hz})\end{array}$ & $\begin{array}{c}\text { 導電率 } \\
(\mu \mathrm{S} / \mathrm{cm})\end{array}$ \\
\hline 固体粒子 & 1.17 & 22.5 & $1.62 \times 10^{-3}$ \\
ジメチルシリコーン & 0.97 & 7.3 & $1.40 \times 10^{-9}$ \\
ハイドロジェンシリコーン & 0.96 & 6.4 & $1.47 \times 10^{-9}$ \\
不能和基含有化合物 & 1.16 & 6.2 & $6.26 \times 10^{-9}$ \\
供試シリコーンゲル & 0.99 & 9.3 & $1.18 \times 10^{-3}$ \\
\hline
\end{tabular}

ゲルの物理定数を示す。ゲルに電圧を印加したとき流れる 電流は、殆ど粒子の導電率によって決定されると言える が、電気伝導は粒子の繫がりに重要な働きがあると考えら れる。すなわち、同じ印加電圧に対して、供試シリコーン ゲルの電流值は、粒子の濃度が増加すると共に非線形的に 増加する。これは、電気伝導のメカニズムがパーコレー ション理論によって説明できる可能性を暗示する。

$<2 \cdot 2>$ 供試ゲルの電気粘弾性测定 分散系シリ コーンゲルに電界を印加すると、その粘弾性特性は、ゲル 中に分散した粒子間の引力による凝集効果によって影響さ れるものと考えられる。すなわち、 E R 材料としてのゲル は、電界の印加による $\mathrm{E} R$ 効果発現の大きさと粘弾性特性 の両者によって評価され得る。

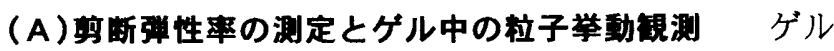
の基本的な弾性定数として、まず電界の有無による剪断弾 性率 $G$ が測定された。Gの值は、平行平板電極(電極サイ ズ : $50 \mathrm{~mm} \times 70 \mathrm{~mm}$ 、ギャッブ長 : $d=2 \mathrm{~mm}$ ) 間に供試ゲ ルを電極に密着させて挿入し、上部電極 (高電圧電極)に一 定の剪断力 (電極に平行な力) を加えた時、下部電極(接地電 極)に現れる応力 $\Delta \tau$ とひずみ $\Delta \gamma(=\Delta x / d: \Delta x$ は上部電極 の変位を表す)との比、 $\Delta \tau / \Delta \gamma$ から求めた。 $\Delta \tau$ は下部電 極に直結されたロードセルで測定し、ゲルに囬加する電界 $E$ は $2.0 \mathrm{kV} / \mathrm{mm}$ の範囲で可変した。なお、この方法で $G$ を導出する場合には、供試ゲルがフッキアン弾性体と見 なせる範囲の微少な変位に対して応力を検出する必要があ る。種々の変位 $(\Delta x)$ に対するゲルの変形を顕微鏡で観測し た結果、供試ゲルは $\Delta x=0.1 \mathrm{~mm}$ 程度以下の変位でフッキア ン弾性体のように振る舞うことが分かった。従って、Gを 導出する際のひずみは $\Delta \gamma=0.05$ として測定した。また、無 電界時 $(E=0)$ の供試ゲルにおいて、変形による密度変化の 目安を得るため、一定加重に対する微少変位の測定からポ アソン比 $p$ を求めた。

更に、供試ゲルに電界を印加した場合、ゲル中に分散す る粒子が如何なる挙動を示すかについて調べた。2 枚の線 状金属薄板(厚さ約 $0.1 \mathrm{~mm}$ ) がスライドガラス板に $2 \mathrm{~mm} の$ ギャップを隔てて平行に張り付けられた電極系を準備し た。厚さ約 $0.1 \mathrm{~mm}$ 程度にスライスした供試ゲルをこの電極 
系のギャップ中に挿入し、上からカバーグラスで封止して 光学顕微鏡に据え付け、電界の有無による粒子挙動を観測 した。

（B 動的粘弾性の測定 粘弾性体に振動を与えて応力、 またはひずみを時間的に変化させた場合に見られる粘弾性 挙動は、動的特性と言われる。これはレオロジーの分野に おいて、粘弹性体の性質を特徴づける手段として一般に採 用されている(17)。本研究では、周波数範囲 $0 \sim 1 \mathrm{~Hz}$ の超低周 波正弦振動を発生する平行平板型レオメーターを使用し て、供試ゲルの振動に対する剪断応力を $2.0 \mathrm{kV} / \mathrm{mm}$ までの 直流電界印加の下で測定した。これに基づき供試ゲルの電 気粘弾性評価として、複素弾性率 (貯藏弾性率と損失弾性 率)、及び損失正接を調べた。

図 1 は、供試ゲルの動的特性を測定する為に試作した装 置の概略図を示す。

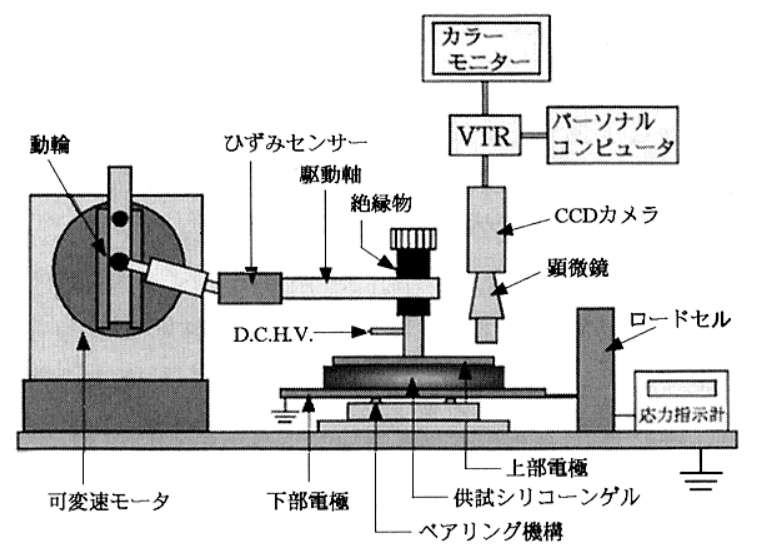

図1 供試ゲルの動的特性測定装置概略図

Fig. 1 Schematic diagram of apparatus used for measurement of dynamic properties.

供試ゲルは、ギャップ長 $d(d=2 \mathrm{~mm})$ を持つ平行平板電 極間に電極と完全に密着するように挟み込まれた。上部電 極 (電極サイズ : $50 \mathrm{~mm} \times 70 \mathrm{~mm}$ ) は、駆動軸と動輪を介し て可変速モ一夕 $(N=0 \sim 60 \mathrm{rpm})$ に接続されている。これ によって、上部電極の動きはモータの回転数に応じた周波 数 $f$ の水平正弦振動に変換される。従って、強制的な正弦 振動応力により、次式で示されるような剪断ひずみ $\gamma$ が供 試ゲルに与えられる。

$$
\gamma=\gamma_{o} \exp (i \omega t)
$$

ここで、 $\gamma_{o}$ は剪断ひずみの振幅であり、 $\gamma_{o}=x_{m} / d\left(x_{m}\right.$ : 水平振動の振幅) として定義される。 $i$ は虚数単位、 $\omega(=$ $2 \pi f)$ はひずみの角周波数、及び $t$ は時間を表す。 $\gamma_{0}$ の值 は動輪の半径を調整することによって、0 0.625の範囲で 調整された。なお、上部電極と駆動軸とは電気的に絶縁さ
れ、高電圧を印加することができる。下部電極は接地さ れ、ベアリング機構によって水平方向に自由に可動でき る。また、下部電極にはロードセル ( $3 \mathrm{kgf}$ 定格) が直結さ れ、これによって下部電極にかかる応力 $\tau$ を測定した。一 般に、外加ら物体に対して力 $F$ を加えると、物体は反作用 によって、外力 $F$ と同じ大きさで反対方向の力を外に及ぼ す。従って、上記の上部電極に加えた応力の大きさは、下 部電極にかかる応力 $\tau$ の大きさと等価であると見なせる。 加えて、この実験では外部応力を与えた場合のゲルに生じ るひずみの様相が、C C D カメラとカラーモニターを用い て観測された。測定は全て室温の温度条件でなされた。

\section{3．実験結果および考察}

\section{<3・1> シリコーンゲル中に分散する粒子の挙動}

供試ゲルに直流電界を印加すると、その直後に粒子は電 界の方向に配列し、電極間が粒子の鎖によって架橋される ことが観測された。図 2 は、供試ゲル中に分散する粒子の 電界の有無による代表的な様相を示す。無電界時 $(E=0)$ に

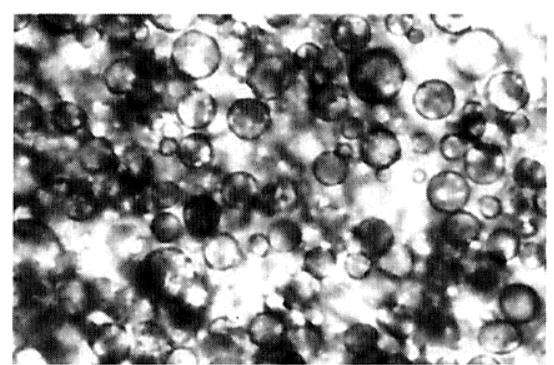

(a) $E=0$

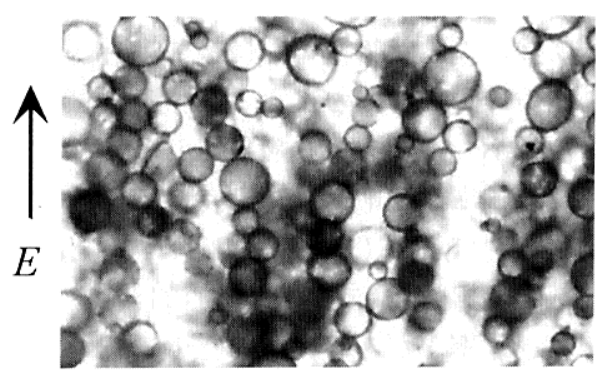

(b) $E=2.0 \mathrm{kV} / \mathrm{mm}$

図 2 供試ゲル中に分散する粒子の代表的様相

Fig. 2 Typical example of appearance of particles in silicone gel.

おいて、粒子はゲル組織の中にランダムな配置で存在して いる(図 2 (a))。電界を印加すると、図 2 (b)に示されるよう な鎖状構造が形成される。これらの現象は E R 流体の電界 印加時に生じる粒子の挙動と類似していることから、供試 ゲルもまた E R 効果の発現が期待される。しかし、粒子の 鎖状構造に関して、ゲルと E R 流体との間には次の二つの 相違点が見られる。（1）E R流体中の鎖状構造は電界の除 
去により、短時間で崩壊するのに対して、ゲル中の鎖状構 造は長時間にわたって記憶される。これは、ゲル中で鎖状 に配列した粒子が、電界を除去した後もゲルの組織に捕獲 された状態が長く維持される為である。従って、無電界時 $(E=0)$ におけるゲル中の鎖状構造は見かけのものであり、 この時の粒子間引力は消失していると考えられる。(2) E $\mathrm{R}$ 流体中に形成される粒子の鎖は、電極間でほぼ直線的に 生じるが、ゲル中の鎖は蛇行した構造を示す（図 2 (b)におい て、粒子の鎖は平面上に整列していない)。これは、ヒドロ シリル化反応によって形成されるゲル組織の形成過程に起 因するものと考えられる。すなわち、この反応によるゲル 化過程において、数個の粒子を包み込むような細胞壁を持 つ組織が形成され、細胞壁内は液体相が多く含まれている かの様に思える。このことは、供試ゲルをカミソリ刃など で傷付けると、その傷口からオイルがしみ出てくる現象か ら予想される。このようなゲルに電界を印加すると、各々 の細胞壁内に存在する粒子がまず電界方向に小鎖となって 繋がり、これらが、隣接する紐胞壁内の小鎖と 3 次元的に 順次連結する為、電極間に形成される鎖状構造が空間的に 蛇行した形を取るものと考えられる。一方、供試ゲルを平 行平板電極間に挟み電界を助加した後、電界と直角方向に 剪断変位を与えた場合、粒子の鎖は切断すること無く、変 位の方向に約 $40^{\circ}$ の角度まで傾斜することが観測された。 しかし、更に大きな変位に対しては、ゲルと電極表面との 間ですべりが生じ、電極表面付近でゲルの組織が崩壊する と共に粒子の鎖も切断された。

\section{<3・2> 供試ゲルの站弾性に関する界の効果}

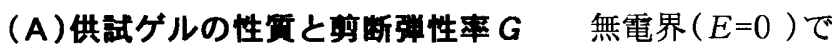

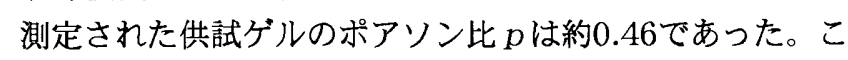
れは、供試ゲルがゴム状物質または液体に近い性質、すな わち、単純圧縮 (または伸長)による体積変化が殆ど無い材 料であることを示している。一般に、シリコーンゲルの組 織は化学的に架橋された網目構造を持っており、構造的に 安定な分子間結合によってゲル弾性を示すことが知られて いる。また、材料の弾性(または剛性)の程度を反映する定 数の一つにヤング率 $Y$ があり、等方性のフッキアン弾性体 に対しては剪断弾性率 $G$ とポアソン比 $p$ にって、 $Y=2 G$ $(1+p)$ のように関係づけられている。ゲルやゴム状物質の ヤンク率は、通常 $10^{4} \sim 10^{6} \mathrm{~Pa}$ 程度(例兄ば、ゼラチンゲル では、 $Y=(0.2 \sim 2) \times 10^{5} \mathrm{~Pa}(p=0.5)$ 、天然ゴムでは、 $Y$ $=(0.8 \sim 2) \times 10^{6} \mathrm{~Pa}(p=0.49)$ など $)$ であるが、更に低いヤ ング率を持つゲル状物質もある(例えば、プリン(森永製菓 製)では、 $Y=5 \times 10^{2} \mathrm{~Pa}(p=0.47)$ である)。

表 2 は、供試ゲルにおける剪断弾性率 $G$ の電界 $E$ による 変化を示す。無電界時 $(E=0)$ における供試ゲルのヤング率 は、 $G$ との測定値より約 $4.4 \times 10^{2} \mathrm{~Pa}$ であことが算出さ れる。この值は、通常のゲル状物質と比較して約 $2 \sim 3$ 枌も 小さく、上記のプリンに似た剛性を持つ極めてソフトなゲ ルと言える。一方、供試ゲルに電界を印加し、0から
表 2 供試シリコーンゲルの剪断弾性率 $G$

Table 2 Shear modulus $G$ of silicone gel.

\begin{tabular}{|c|c|c|c|c|c|c|}
\hline $\begin{array}{r}\text { 電界強度 } E \\
(\mathrm{kV} / \mathrm{mm})\end{array}$ & 0.0 & 0.5 & 1.0 & 1.5 & 1.75 & 2.0 \\
\hline $\begin{array}{r}\text { 剪断弾性率 } G \\
(\mathrm{kPa})\end{array}$ & 0.15 & 0.54 & 1.2 & 1.9 & 2.4 & 3.1 \\
\hline
\end{tabular}

$2.0 \mathrm{kV} / \mathrm{mm}$ まで上昇させると、Gの值は無電界時 $(E=0)$ のそれの約21倍まで増加した。これは、供試ゲルが電界の 印加によって E R 効果を発現できることを暗示している。

（B）供試ゲルの動的站弾性特性前項 (A)で示した剪 断弾性率 $G$ は、弾性論において粘性流動を考虑せず、供試 ゲルがフッキアン弾性体と見なせる微少な変位に対する場 合に限って測定されたものである。しかし、更に大きな変 位に対しては、弾性的要素と粘性的要素の両者を合わせ持 つ粘弾性の特性を示すものと考えられる。また、ゲルに振 動的な剪断応力を与えると、時間と共に変化する剪断ひず みによって、ゲルの内部時間スケールは変形の時間スケー ルに依存して変化し、これに対応した粘弾性挙動を示すも のと考えられる。もし、供試ゲルがフッキアン弾性体と ニュートニアン粘性体の中間の特性を持つとすれば、剪断 ひずみ $\gamma$ と剪断応力 $\tau$ との間に、角度 $\delta\left(0<\delta<90^{\circ}\right)$ の位 相差が存在せねばならない。すなわち、材料がフッキアン 弾性体であれば、フックの法則より正弦振動応力とひずみ は同一位相となるが、ニュートニアン粘性体では、ニュー トンの粘性法則よりひずみは応力より $90^{\circ}$ 位相が遅れて現 れる。従って、粘弾性体では両者の要素が混合され、ひず みの位相が応力のそれより $\delta$ だけ遅れる。

本実験の場合 (図 1)、下部電極にかかる応力 $\tau$ は剪断ひ ずみ $\gamma$ に対して、次式のように表される。

$$
\tau=\tau_{0} \exp \{i(\omega t+\delta)\}
$$

ここで、 $\tau_{0}$ は剪断応力 $\tau$ の振幅を表す。また、 $\delta$ は損失角 と言われ、上部電極の剪断変位と下部電極にかかる応力 $\tau$ との同時測定による正弦波形の位相差から測定した。この ような粘弾性物質の挙動を特性化する方法としては、Maxwell モデル、Kelvinモデル、及びそれらを混合した多 要素モデルなどが提案されている(17)。本研究では、低周 波正弦ひずみに応じた正弦応力を見ることから、 Kelvin モデルを用いて、供試ゲルの複素弾性率 $G^{*}$ (貯蔵弾性率 $G$ 'と損失弾性率 $G$ ”) 、及び損失正接 $(\tan \delta)$ を調べた。

Kelvinモデルの静的挙動に対する関係式は、（3）式で表 される。

$$
\tau=G \cdot \gamma+\eta(d \gamma / d t)
$$


ここで、クは粘性係数を表す。（3）式の右辺第一項は弾性 変形、及び第二項は流動変形を表す。また、動的挙動に対 しては、（1）式の正弦ひずみを（3）式に導入することに よって、（2）式の正弦応力が得られる。この場合におい て、応力とひずみは共に複素数であり、 $G^{*}$ とtan $\delta$ はフッ キアンの定義 (弾性率=応力/ひずみ)に従って次のように 与えられる。

$$
\begin{aligned}
G^{*} & =G{ }^{\prime}+i G ” \\
& =G\left(1+\omega^{2} \lambda^{2}\right)^{1 / 2}(\cos \delta+i \sin \delta) \\
& =G(1+i \tan \delta)
\end{aligned}
$$

$$
\tan \delta=G " / G{ }^{\prime}=\omega \lambda
$$

ここで、 $\lambda$ は変形の遅延時間を表す。

図 3 は、 $\gamma_{0}=0.5$ における $\tau_{0}-f$ 特性の電界依存性を 示す。 $\tau_{0}$ の值は電界 $E$ 上昇すると著しく増加した。 $E$ 二一定の下では、 $E \leqq 0.5 \mathrm{kV} / \mathrm{mm}$ 、及び $f \leqq 0.25 \mathrm{~Hz}$ の範 囲での変化を除いて、 $\tau_{0}$ の $f$ にる変化は殆ど見られな かった。また、同図中で示されるように、各特性を $f=0$ まで外装した時の応力は降伏応力 $\tau_{y}$ と見なされる。一 般に、ゲル状物質は非ニュートン流動の特性を示し、特に 柔らかいゲルの降伏応力 は極めて小さいとされている。 この関係は、同図の $E=0$ の場合に見られ、 $\tau_{y}$ 值は極め て小さい。

上記の $E$ と $f$ 小さな範囲 $(E \leqq 0.5 \mathrm{kV} / \mathrm{mm}$ 、及び $f \leqq$ $0.25 \mathrm{~Hz})$ で生じる $\tau_{0}$ の変化は、構造粘性の現象によるも

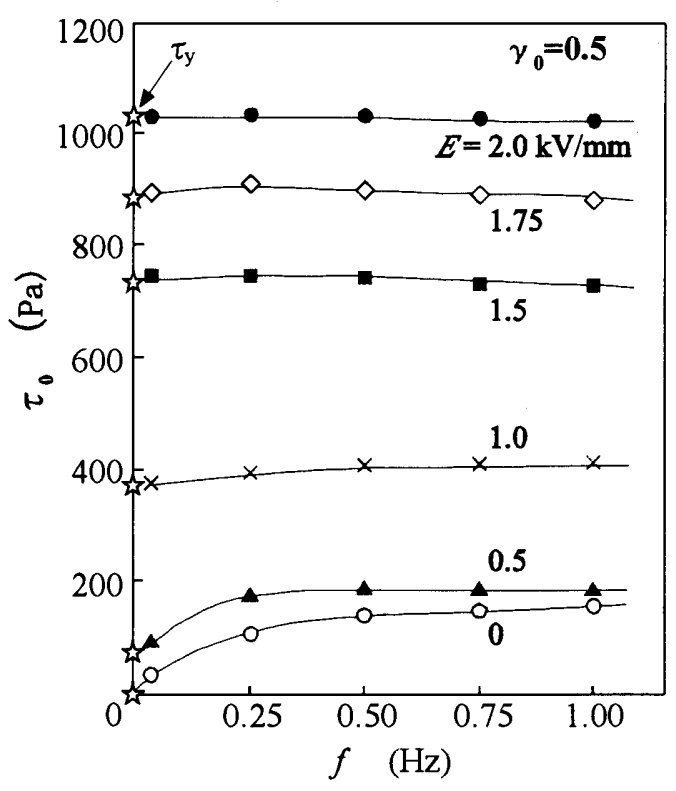

図3 $\tau_{0}-f$ 特性の電界依存性

Fig. $3 E$ dependence of relationship berween $\tau_{0}$ and $f$.
のと考えられる。すなわち、本研究で試作したシリコーン ゲルにおいて、電界強度が小さい場合、粒子は互いに弱い 引力で結合され、ゲルが静止した状態での粒子は弱い構造 を作っているため、剪断力を加えると弱いものから順次破 壊分散されて粘度が減少し応力の変化が見られる。また、 $f$ を上昇させると、ゲルは徐々に二ュートン流動的に振る 舞うようになり、応力(あるいは粘度)の変化が小さくなる ものと考えられる。一方、電界を上昇し、 $E \geqq 1 \mathrm{kV} / \mathrm{mm}$ の範囲では非常に大きな $\tau_{y}$ 值となる。これは、供試ゲル 中に分散する粒子相互の引力増加に伴う凝集効果 (粒子の 鎖状構造)によって、剪断に対する抵抗力、すなわち、 $\mathrm{E}$ $\mathrm{R}$ 効果が発現し、ゲルがビンガムの降伏值を有する物質に 移行したことを示している。

図 4 は、 $\gamma_{0}=0.5$ における $\tan \delta$ と $E$ の関係を示す。tan $\delta$ の値は、周波数が特に低い場合 $(f=0.03 \mathrm{~Hz})$ のみ、 $E$ と 無関係にほぼ一定值を示したが、 $f \geqq 0.25 \mathrm{~Hz}$ では、Eが 0 から $0.5 \mathrm{kV} / \mathrm{mm}$ の変化において大きく減少し、 $E \geqq 1$ $\mathrm{kV} / \mathrm{mm}$ ではほぼ一定值であった。また、一定の $E$ に対 する $\tan \delta$ は $f$ の上昇と共に上昇した。 $\tan \delta$ は粘弾性物質 の弾性が内部摩擦によって失われる度合いを表す。従っ て、同図の結果は、Eの上昇(または $f$ の減少)によって、 供試ゲルの弾性要素が強化されることを示している。しか し、同図の特性は全て $\tan \delta \geqq 1$ であることから、供試ゲ ルはいずれも粘性要素の大きな材料であると言える。これ らの関係はまた、複素弾性率 $G^{*}$ の特性に反映される。

図 5 は、 $\gamma_{0}=0.5$ における $G^{*}(G$ 及ひび $G ”)$ と $E$ 関 係を示す。 $G$ 'と $G ”$ の值は $E$ の上昇と共に增加し、 $G ”$ は $f$ の上昇と共に増加する。 また、 $G{ }^{*}<G ”$ の関係が

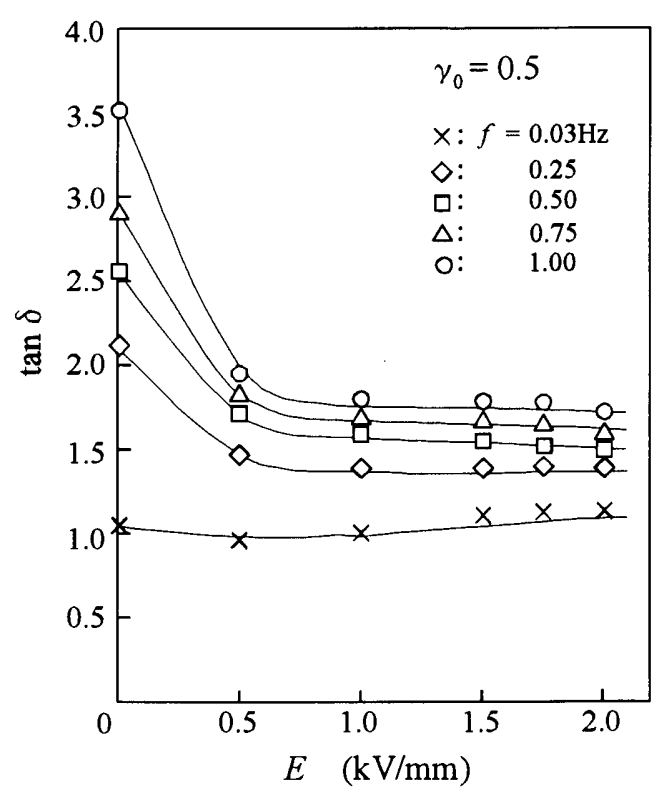

図4 $\tan \delta$ と $E$ の関係

Fig. 4 Relationship between $\tan \delta$ and $E$. 


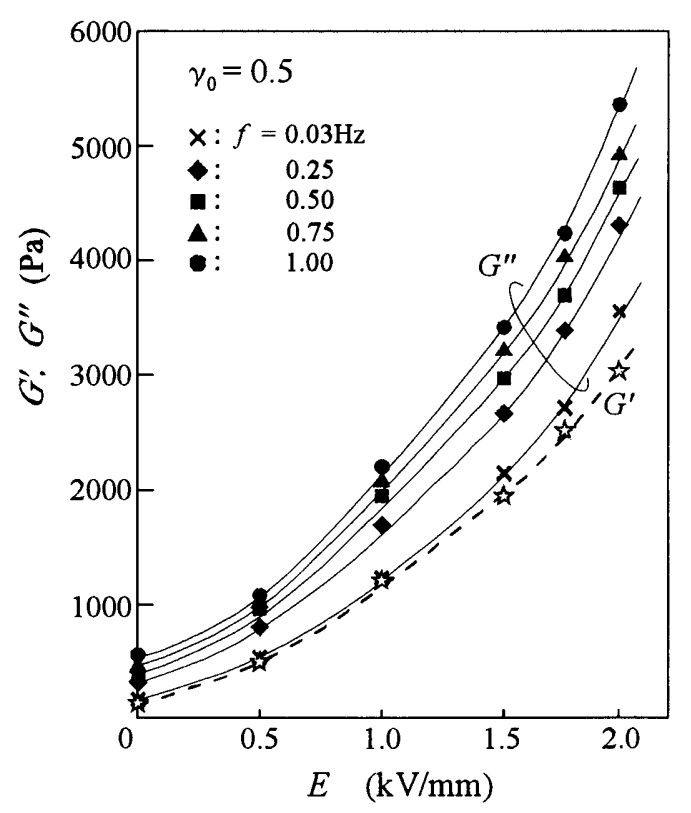

困5 $G^{*}\left(G^{\prime}\right.$ and $\left.G^{\prime \prime}\right)$ と䜿関係

Fig. 5 Relationship between $G^{*}\left(G^{\prime}\right.$ and $\left.G^{\prime \prime}\right)$ and $E$.

成り立つ。Kelvinモデルにおいて、材料の遅延時間 $\lambda$ と 実験のタイムスケール $T(=1 / f)$ とがほぼ同じ場合に粘弾

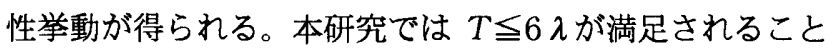
から、供試ゲルが粘弾性体に属すると言える。

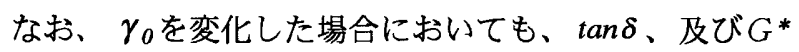
とEの関係を測定したが、いずれも図 4 、図 5 と殆ど同じ 傾向を示した。しかし、 $\tan \delta と G ”$ は $\gamma_{0}$ の上昇に伴って 増加することが分かった(例えば、 $E=1.5 \mathrm{kV} / \mathrm{mm} 、 f=$ $0.5 \mathrm{~Hz}$ の場合、 $\gamma_{0}=0.25 \sim 0.625$ の変化に対して、 $\tan \delta$ $\fallingdotseq 1.2 \sim 1.7 、 G ” \fallingdotseq 2.3 \sim 3.2 \mathrm{kPa}$ に変化した)。

一方、粘弾性体に周期的なひずみ(または応力)を加える と、材料の粘性要素によって、外部から与えられた力学的 エネルギーは熱エネルギーに変換される。その度合いを表

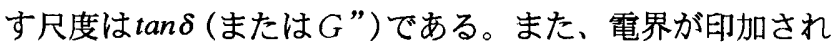
ると、これによる電気的エネルギ一も熱エネルギーに変換 される。材料に正弦ひずみ $\gamma$ と電界 $E$ を与えた場合、ひず みの 1 サイクル当りに消散される全エネルギー $W$ は、次 式で表される。

$$
\begin{aligned}
W & =\int_{0}^{2 \pi / \omega}\{\tau(d \gamma / d t)+E \cdot J\} d t \\
& =\pi \gamma_{0}^{2} G^{\prime} \tan \delta+E \cdot J / f
\end{aligned}
$$

ここで、 $J$ は電流密度を表し、右辺第 1 項は力学的エネル ギ一消散 $W_{V}$ 、及び第 2 項は電気的エネルギー消散 $W_{P}$ を 表す。供試ゲルの $J$ は、 $E=0 \sim 2 \mathrm{kV} / \mathrm{mm}$ の印加電界に対
して、 $J=0 \sim 2.2 \mu \mathrm{A} / \mathrm{cm}^{2}$ の範囲で非線形的に変化した。 また、前述したように供試ゲルの粘性要素が大きいことか ら $W_{V}$ も大きくなると考えられるが、電界印加時のJに伴 う $W_{P}$ と比較して $W_{V}<W_{P}$ となることが分かった。例 えば、 $\mathrm{E}=1.5 \mathrm{kV} / \mathrm{mm} 、 \gamma_{0}=0.5 、 f=1.0 \mathrm{~Hz}$ におい て、 $W_{V} \fallingdotseq 2.6 \times 10^{-3} \mathrm{~J} / \mathrm{cm}^{3}$ 、及び $W_{P} \fallingdotseq 1.4 \times 10^{-2} \mathrm{~J} /$ $\mathrm{cm}^{3}$ であった。

\section{4.まとめ}

従来のER流体における重要な問題点として、不十分な 「分散安定性」が指摘されている。この問題の一解決法とし て、E R流体のゲル化が提案され、微粒子分散系シリコー ンゲルが試作された。本研究では、このゲルについて、電 界印加時における粒子の挙動と電気粘弾性特性を調べた。 得られた結果は以下に要約される。

（1）供試ゲルに直流電界を刋加すると、電極間が粒子の鎖 状構造によって架橋されることが分かった。この鎖状構造 は蛇行した形を示し、電界を除去しても長時間にわたって 記憶された。また、卵加した電界と直角方向に剪断変位を 与えると、粒子の鎖は切断すること無く変位の方向に約 $40^{\circ}$ の角度まで傾斜した。更に大きな変位に対しては、ゲルと 電極表面との間ですべりが生じて電極表面付近のゲル組織 が崩壊し、同時に粒子の鎖も切断された。

(2) 無電界時 $(E=0)$ における供試ゲルの剪断弾性率 $G$ は、通常のゲル状物質より非常に小さく、ポアソン比 $p$ は約 0.46 であった。これより、供試ゲルが極めてソフ トな材料であり、ゴム状物質や液体に近い性質を持つこと が分かった。また、 $E=0 \sim 2.0 \mathrm{kV} / \mathrm{mm}$ の範囲で電界を 印加すると、Gの值は $E=0$ における值の約 21 倍まで増 加した。

( 3 )ひずみに対する剪断応力の振幅 $\tau_{0}$ は、電界 $E$ の上昇 によって著しく増加した。また、降伏忍力 $\tau_{y}$ は、 $E=0$ においては殆ど現れないが、 $E \geqq 1 \mathrm{kV} / \mathrm{mm}$ では大きな值 となる。これらより、供試ゲルが $\mathrm{E} \mathrm{R}$ 効果を発現できる材 料であることが示された。また、損失正接 $(\tan \delta)$ と複素 弾性率 $G$ *の特性から、供試ゲルは粘性要素の大きな材料 であるが、粘弾性体として振る舞うことが分かった。

本研究で試作したシリコーンゲルは、分散安定性(粒子沈 降)の問題を考慮外として E R 効果を発現できる新しい E R 材料と言える。このようなゲルを工業的に応用する場合、 デバイスからの液漏れが無く、複雑なシール機構などは不 要である。しかし、大きな剪断変位が作用すると、ゲルの 組織が崩壊して E R 効果の発現が低下する。従って、用途 としては、例えば、吸震、防音などを目的とした小さな剪 断変位を対象とする装置に適するものと言える。

最後に、本研究の一部は文部省科学研究費の援助を受け て行われたことを記し謝意を表す。

(平成13年7月 30 日受付、平成13年11月7日再受付) 


\section{文献}

(1) W. M. Winslow: "Induced Fibration of Suspensions", J. Applied Physics, Vol. 20, pp. 1137-1140 (1949)

(2) 花岡、堀田、安齋、桜井、黒田: " 直流電界下におりる分散系 $\mathrm{E}$ R 流体の内部構造と E R 特性”、電気学会論文誌A、Vol.. 119A、No. 6、pp. 750-757 (1999)

(3) H. Block and J. P. Kelly: "Electro-Rheology", J. Phys. D: Appl. Phys., Vol. 21, pp. 1661-1677 (1988)

(4) A. P. Gast and C. F. Zukoski: "Electrorheological Fluids as Colloidal Suspensions", Adv. Colloid Interface Sci., Vol. 30, pp. 153-202 (1989)

(5) D. Klass and T. W. Martinek: "Electroviscous Fluids. I. Rheologocal Properties", J. Applied Phys., Vol. 38, No. 1, pp. 67-74 (1967)

(6) D. Klass and T. W. Martinek: "Electroviscous Fluids. II. Electrical Properties", J. Applied Phys., Vol. 38, No. 1, pp. 75-80 (1967)

(7) H. See, H. Tamura and M. Doi: "The role of water capillary forces in electrorheological fluids", J. Phys. D:Appl. Phys., Vol. 26, pp. 746-752 (1993)

(8) H. Tamura, H. See and M. Doi: "Model of porous particles containing water bin electrorheological fluids ", J. Phys. D:Appl. Phys., Vol. 26, pp. 1181-1187 (1993)

(9) J. N. Foulc, P. Atten and N. Felici: "Macroscopic Model of Interaction between Particles in an Electrorheological Fluid", J. Electrostatics, Vol. 33, pp. 103-112 (1994)

(10) N. Felici, J. N. Foulc and P. Atten: "A Conduction Model of Electrorheological Effect "「Electrorheological Fluids」, Eds: R. Tao and G. D. Roy, World Scientific Publishing, Singapore, pp. 139-152 (1994)

(11) P. Atten, C. Boissy and J. N. Foulc: "The Role of Conduction in Electrorheological Fluids: from Interaction between Particles to Structuration of Suspensions", J. Electrostatics, Vol. 40 \& 41, pp. 3-12 (1997)

花岡、高田、村雲、桜井、安䀺 : " 分散系E R流体の粒子凝集力 に関する電気伝導の役割"、電気学会論文誌 A、Vol.. 121-A、

No. 2、pp. 136-142 (2001)

R. Hanaoka, S. Takata, M. Koike, T. Fukami, K. Sakurai and H. Anzai: "Temperature Dependence of Electrical Response of Aqueous and Nonaqueous ER Fluids ", Proc. of 2nd Conf. on Electrostatics, pp. 161-165 (2000)

(14) T. Shiga, T. Ohta, Y. Hirose, A. Okada and T. Kurauchi: "Electroviscoelastic Effect of Polymeric Composites Consisting of Polyelectrolyte Particles and Polymer Gel", J. Materials Science, Vol. 28, pp. 1293-1299 (1993)

(15) T. Shiga, A. Okada and T. Kurauchi: "Electroviscoelastic Effect of Polymer Blends Consisting of Silicone Elastomer and Semiconducting Polymer Particles", Macromolecules, Vol. 26, pp. 6958-6963 (1993)

(16) I. Ojima: "The Hydrosilylation Reaction", 「The Chemistry of Organic Silicon Compounds」 Part 2, Eds: S. Patai and Z. Rappoport, John Wiley \& Sons, An Interscience Publ. (1989)

(17) H. A. Barnes, J. F. Hutton and K. Walters: I. Ojima: AAn Introduction to Rheology J, Elsevier Science (1998)
花岡 良一（正員）1950年1月生まれ。1980年金沢大

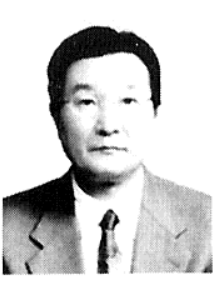
学大学院工学研究科修士課程修了。 1988年4月金沢工業大学電気工学科講師、 89 年同助教授、96年同教授、現在に至 る。主として、液体誘電体中の電気伝導と 絶縁破壞、沿面放電現象、電界計算法、及 びER流体の高性能化に関する研究に従 事。1993年9月～94年8月米国MIT客員研究員。工学博士。 応用物理学会会員、IEEE会員。

高田 新三（正員）1945年5月生まれ。1975年明治大 学大学院工学研究科博士課程修了。1974 年4月金沢工業大学電気工学科講師、75年 8月同助教授、81年同教授、現在に至る。 磁性材料、薄膜EL素子用材料、透明導電 膜用材料等電気電子材料の研究開発に従 事。1997年7月～98年6月米国ハワイ州立 大学客員教授。工学博士。応用物理学会会員、電気化学会 会員、American Vacuum Society 会員。

中澤 優一（非会員）1979年3月生まれ。2001年3月金

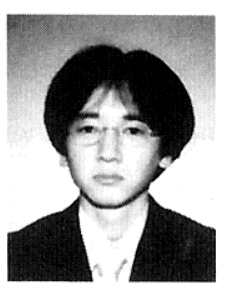
沢工業大学工学部電気工学科卒業。同年 4 月同大学大学院工学研究科修士課程入学、 現在に至る。主としてER流体の高性能化 に関する研究に従事。

深見 正

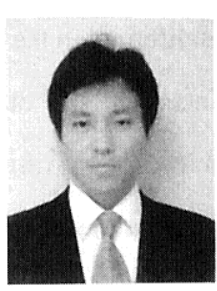

（正員） 1962年12月生まれ。1990年3月 金沢工業大学大学院博士課程修了。同年4 月三菱電機(株) 入社、中央研究所に勤務。 1992 年4月金沢工業大学電気工学科助 手、講師を経て、97年同助教授、現在に 至る。工学博士。第 1 種電気主任技術者。 IEEE会員。

桜井 宏治 （非会員） 1960年12月生まれ。1983年3月 東海大学工学部工業化学科卒業。同年4月

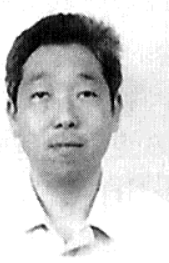
藤倉化成 (株) 入社、現在に至る。主とし て、トナ一用樹脂設計、及び製造プロセ ス、粉体物性、ER現象に関する研究に従 事。高分子学会会員。 